\title{
The palaeogeography of Sundaland and Wallacea since the Late Jurassic
}

\author{
Robert HALL* \\ Southeast Asia Research Group, Department of Earth Sciences, Royal Holloway University of London, Egham, Surrey TW20 0EX, UK \\ *Corresponding author: robert.hall@es.rhul.ac.uk
}

\begin{abstract}
The continental core of Southeast (SE) Asia, Sundaland, was assembled from Gondwana fragments by the Early Mesozoic. Continental blocks rifted from Australia in the Jurassic [South West (SW) Borneo, East Java-West Sulawesi-Sumba], and the Woyla intraoceanic arc of Sumatra, were added to Sundaland in the Cretaceous. These fragments probably included emergent areas and could have carried a terrestrial flora and fauna. Sarawak, the offshore Luconia-Dangerous Grounds areas, and Palawan include Asian continental material. These probably represent a wide accretionary zone at the Asia-Pacific boundary, which was an active continental margin until the mid Cretaceous. Subduction ceased around Sundaland in the Late Cretaceous, and from about 80 Ma most of Sundaland was emergent, physically connected to Asia, but separated by deep oceans from India and Australia. India moved rapidly north during the Late Cretaceous and Early Cenozoic but there is no evidence that it made contact with SE Asia prior to collision with Asia. One or more arc-India collisions during the Eocene may have preceded India-Asia collision. The arcs could have provided dispersal pathways from India into SE Asia before final suturing of the two continents. During the Late Cretaceous and Early Cenozoic there was no significant subduction beneath Sumatra, Java and Borneo. At about 45 Ma Australia began to move north, subduction resumed and there was widespread rifting within Sundaland. During the Paleogene east and north Borneo were largely submerged, the Makassar Straits became a wide marine barrier within Sundaland, and West Sulawesi was separated from Sundaland but included land. By the Early Miocene the proto-South China Sea had been eliminated by subduction leading to emergence of land in central Borneo, Sabah and Palawan. Australia-SE Asia collision began, eliminating the former deep ocean separating the two continents, and forming the region now known as Wallacea. The microplate or terrane concept of slicing fragments from New Guinea followed by multiple collisions in Wallacea is implausible. Neogene subduction drove extension and fragmentation of Wallacea that caused both subsidence of deep marine basins and elevation of land; topography and bathymetry changed very rapidly, especially during the Pliocene, but the detailed palaeogeography of this region remains uncertain.
\end{abstract}

Key words: SE Asia, geology, subduction, land, sea.

Received: February 2013. Accepted: April 2013.

\section{INTRODUCTION}

This paper aims to give a brief overview of the late Mesozoic and Cenozoic palaeogeography of the Southeast (SE) Asian region, primarily south of Indochina and Thailand. It summarises the main geological events which are discussed in much more detail elsewhere (e.g. Hall, 1996, 2002, 2011, 2012a) and here the focus is primarily on the palaeogeography illustrated by maps that show the main features of the region during the Cenozoic. Discussion of the many problems in making these palaeogeographical sketches can be found in Hall $(1998,2001)$ and other accounts of palaeogeography and geology can be found in Hall $(2009,2012 b)$. I have attempted to keep the number of references to the minimum possible but all these papers include much larger bibliographies with more complete discussion of the geological issues, and several are accompanied by tectonic reconstruction animations which are available at $\mathrm{http}: / /$ searg. rhul.ac.uk/current_research/plate_tectonics/

\section{DISCUSSION}

\section{Mesozoic to Early Cenozoic}

The core of SE Asia (Fig. 1), Sundaland, was initially assembled in the Late Palaeozoic and Early Mesozoic by addition of continental fragments carried from Gondwana (Fig. 2) to SE Asia (Metcalfe, 2011). From the Jurassic onwards much of Indochina southwards through the ThaiMalay Peninsula and parts of the present Sunda shelf as far south as Sumatra was an emergent area of land, probably largely surrounded by subduction zones, implying that the margins included volcanoes and mountains. The limited geological record that is preserved suggests that most of the interior of this region was the site of deposition of terrestrial clastic sediments during the Jurassic and Early Cretaceous (Abdullah, 2009; Racey and Goodall, 2009; Clements et al., 2011).

More continental blocks were added in the Early and early Late Cretaceous (Fig. 2) to form what is now much 
of Borneo, West Sulawesi and Java. The fragments had rifted from Australia in the Late Jurassic and their collisions ended subduction around the SE Asia promontory at about $90 \mathrm{Ma}$. The Woyla intra-oceanic arc of Sumatra was also added to Sundaland at this time. East Java and West Sulawesi are now known to be underlain by Precambrian Australian continental crust rather than Mesozoic accreted crust (Smyth et al., 2007). South West (SW) Borneo was thought to include Palaeozoic metamorphic rocks, and has been regarded as part of a Sunda shield, but our recent work shows that these supposed ancient rocks are largely metamorphosed Cretaceous volcanogenic rocks, although we have a few hints of a Precambrian basement beneath (Davies et al., 2012). These discoveries raise the possibility that the Australian fragments may have brought with them some terrestrial faunal and floral elements from Gondwana in the Cretaceous.

The SW Borneo rocks have often been correlated with metamorphic rocks of Sarawak which were also thought to be Palaeozoic. These too are undated; their age has been inferred from nearby unmetamorphosed limestones of Permo-Carboniferous age with fossils of Cathaysian characteristics (Fontaine, 1990). There are also Triassic sedimentary rocks in Sarawak containing a fossil flora with Asian affinities (Vozenin-Serra, 1977). These rocks had therefore been interpreted as a Palaeozoic metamorphic basement overlain by sedimentary rocks (Hutchison, 2005) accreted to Sundaland during the Sarawak orogeny (Hutchison, 1996) and I had suggested these formed part of a Luconia-Dangerous Grounds block (Hall, 2012a). However, having recently seen these rocks in the field and reconsidered the evidence for the Sarawak orogeny (Hall, 2012a; Hall and Sevastjanova, 2012), I consider it more likely that the metamorphic rocks are not a Palaeozoic basement but instead that Sarawak, the offshore LuconiaDangerous Grounds areas, and Palawan include Asian continental material as well as ophiolitic/arc rocks which probably represent a wide accretionary zone at the AsiaPacific boundary, which was an active continental margin until the mid Cretaceous.

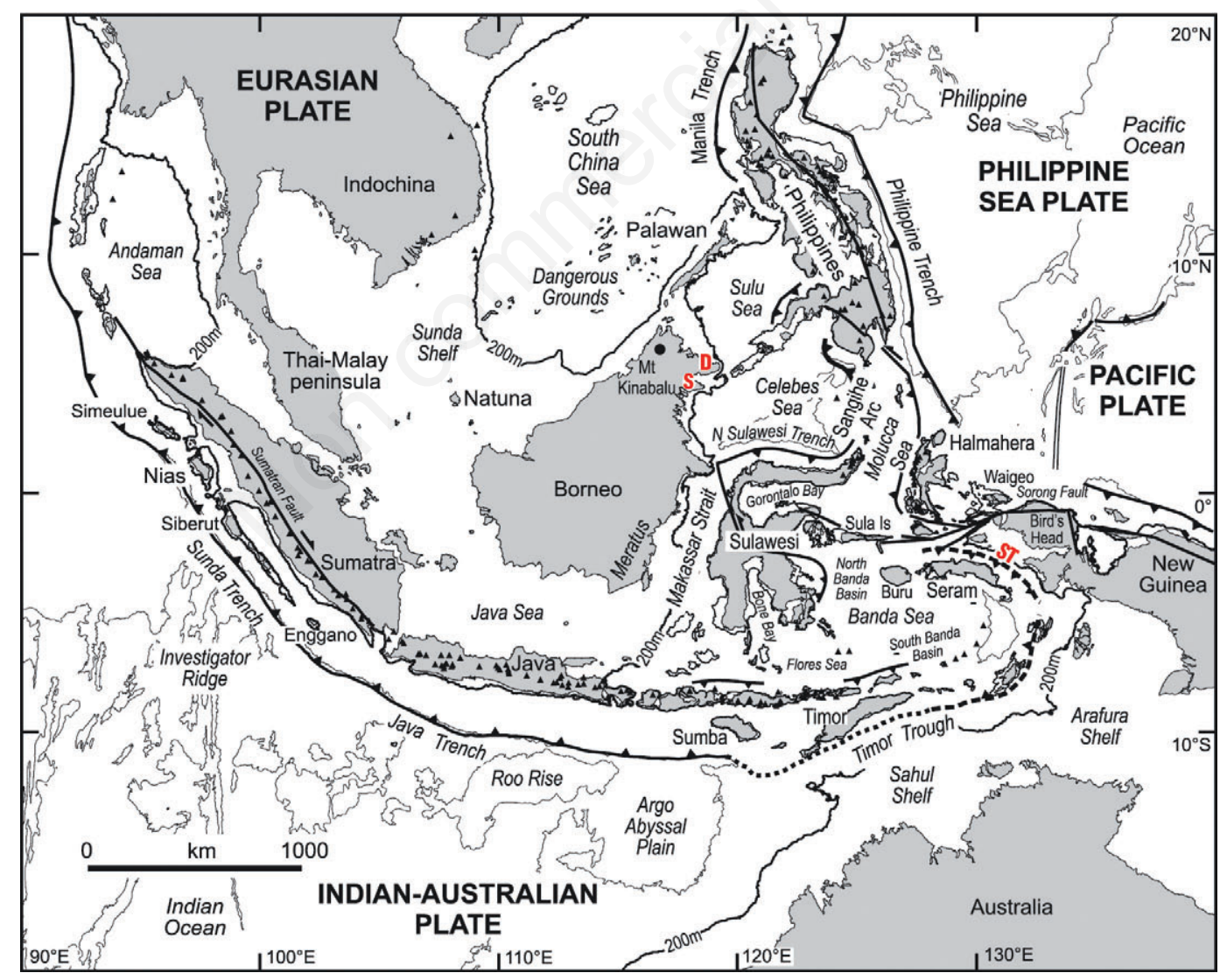

Fig. 1. Simplified geography of Wallacea, Sundaland and surrounding regions. The $200 \mathrm{~m}$ bathymetric contour has been used to define the edge of the Asian margin, Sunda shelf and the Sahul-Arafura shelf. Black filled triangles are volcanoes. Lines with small triangles represent subduction zones with triangles on the upper plate. D and S mark the Dent and Semporna peninsulas of eastern Sabah, and ST is the Seram trough. 
Clements et al. (2011) suggested that the termination of subduction in the early Late Cretaceous contributed to widespread uplift of Sundaland, marked by a major regional unconformity. Rocks below the unconformity are Cretaceous or older, and above are Eocene or younger, representing a time gap of more than 80 million years (Clements et al., 2011). It is reasonable to suppose that most of Sundaland was an emergent region, and mountainous, supported by the presence of Laurasian conifer pollen (Muller, 1968) in Sarawak sandstones, from the Late Cretaceous to Middle Eocene. The few rocks of this age that are preserved, notably in Sarawak and NW Kalimantan, are predominantly terrestrial clastic sediments deposited by rivers, except at the extreme margins of Sundaland in Sarawak, Sabah, West Sulawesi, and probably offshore East Java, where there are poorly dated deep marine clastic deposits. A prolonged period of emergence and widespread reworking of older rocks is suggested by the character of the oldest sediments in the many Cenozoic sedimentary basins that formed throughout Sundaland when sedimentation resumed in the Eocene. They are typically quartz-rich conglomerates and sandstones, very mature in terms of grain shape and composition, suggesting multiple episodes of recycling.

At the end of the Cretaceous subduction resumed beneath West Sulawesi, and continued through the Paleocene (Fig. 3), and there was probably a continental margin volcanic arc, probably more like the present-day
Lesser Sunda islands than a South American Andean margin, with locally emergent islands separated from an interior Sundaland landmass by shallow seas. To the south and east were deep water oceanic areas of the Pacific and Indian oceans.

\section{Cenozoic: Paleogene}

Two geological events are likely to have influenced the distribution of land and sea, and terrestrial biogeographic patterns, in the Sundaland region in the Early Cenozoic. These are the collision of India and Asia, and the resumption of subduction around Sundaland at about $45 \mathrm{Ma}$.

India carried a faunal and floral cargo so the age of connections with SE Asia which would allow dispersals is very important, but a clear-cut answer to many questions is not easy to provide. Ali and Aitchison (2008) have suggested that India could have made contact with the Sumatran part of Sundaland in the Paleocene, before the main India-Asia collision. I see no geological evidence to support this suggestion, but there is evidence for an Indiaarc collision at this time, and it is plausible that the arc could have provided a dispersal route into western Sundaland long before there were continuous land connections from India to Asia. The timing of India-Asia collision remains a controversial issue. There are two main views. The first view is that India-Asia continent-

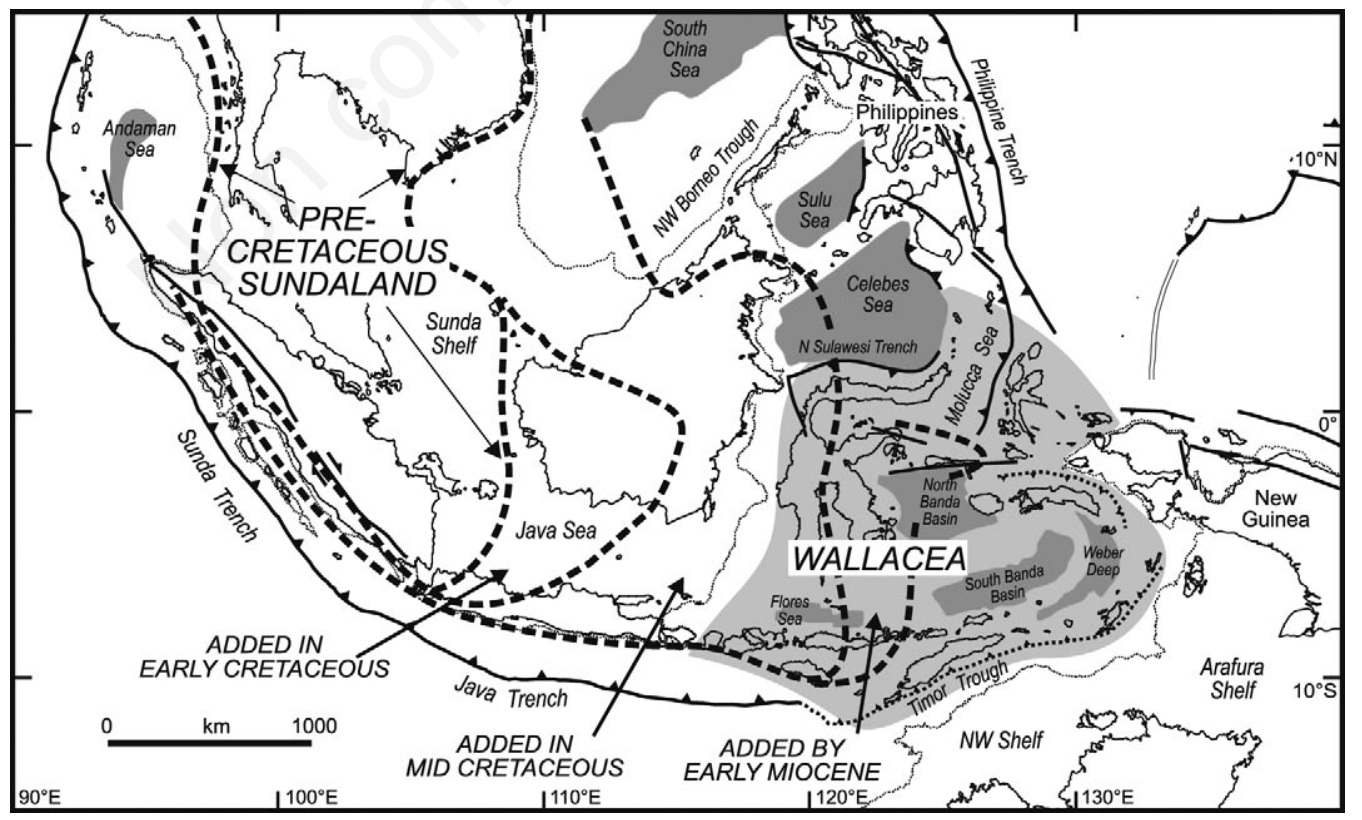

Fig. 2. Sundaland and Wallacea. The heavy dashed lines show the limit of the Sundaland continent at different stages in the Cretaceous and Cenozoic. Wallacea is shaded in light grey. Its western boundary is most commonly drawn through the Makassar straits and across the Celebes sea at Wallace's line and the eastern boundary approximately follows the Australian-New Guinea shelf edge. Darker grey shaded areas are Cenozoic oceanic basins. 
continent collision occurred at about $50 \mathrm{Ma}$ with the implication that from this time it would have been possible for organisms to cross from one continent to another with no marine barriers. The second view is that India-Asia continent-continent collision did not occur before $35 \mathrm{Ma}$ and until that time there would have been marine barriers to dispersal. The geological arguments are many and complex and, as so often is the case, much of the evidence can be interpreted in different ways. Studies of closures of other marine passages, such as the Panama and Indonesian throughflow regions, suggest that a single age of collision may be a misconception. The term collision is used in multiple ways, from the timing of first impact to complete suturing, the detailed record of land and sea is probably never completely reconstructable, and the requirement of geographic connection can be very different for different organisms, ranging from wind dispersal of seeds to continuous freshwater habitats that can allow transit on foot. This is one area where the biologists may be able to help the geologists if they could use fossil and molecular evidence to date appearances of organisms that require complete terrestrial connections.

Until recently, most reconstructions assumed uninterrupted subduction around Sundaland from the Cretaceous into the Cenozoic. However, there is almost no subduction-related igneous record at the Sundaland margins, in contrast to the period before $90 \mathrm{Ma}$ and the period after $45 \mathrm{Ma}$. During the Late Cretaceous and Early Cenozoic there was some oceanic spreading south of Australia, but Australia remained close to Antarctica. I have therefore suggested that subduction beneath Sumatra, Java and Borneo ceased at about $90 \mathrm{Ma}$ and resumed around Sundaland at about $45 \mathrm{Ma}$ as Australia and Antarctica separated and Australia began to move north at a faster rate. Subduction initiation was associated with widespread changes on land and rifting at the Sundaland margins, and by the Middle Eocene (Fig. 4) it appears that much of Sundaland was topographically low. Rivers fed clastic sediments to the Sundaland margins of Sumatra, Java, SE Borneo and Sarawak, implying a still elevated interior which included

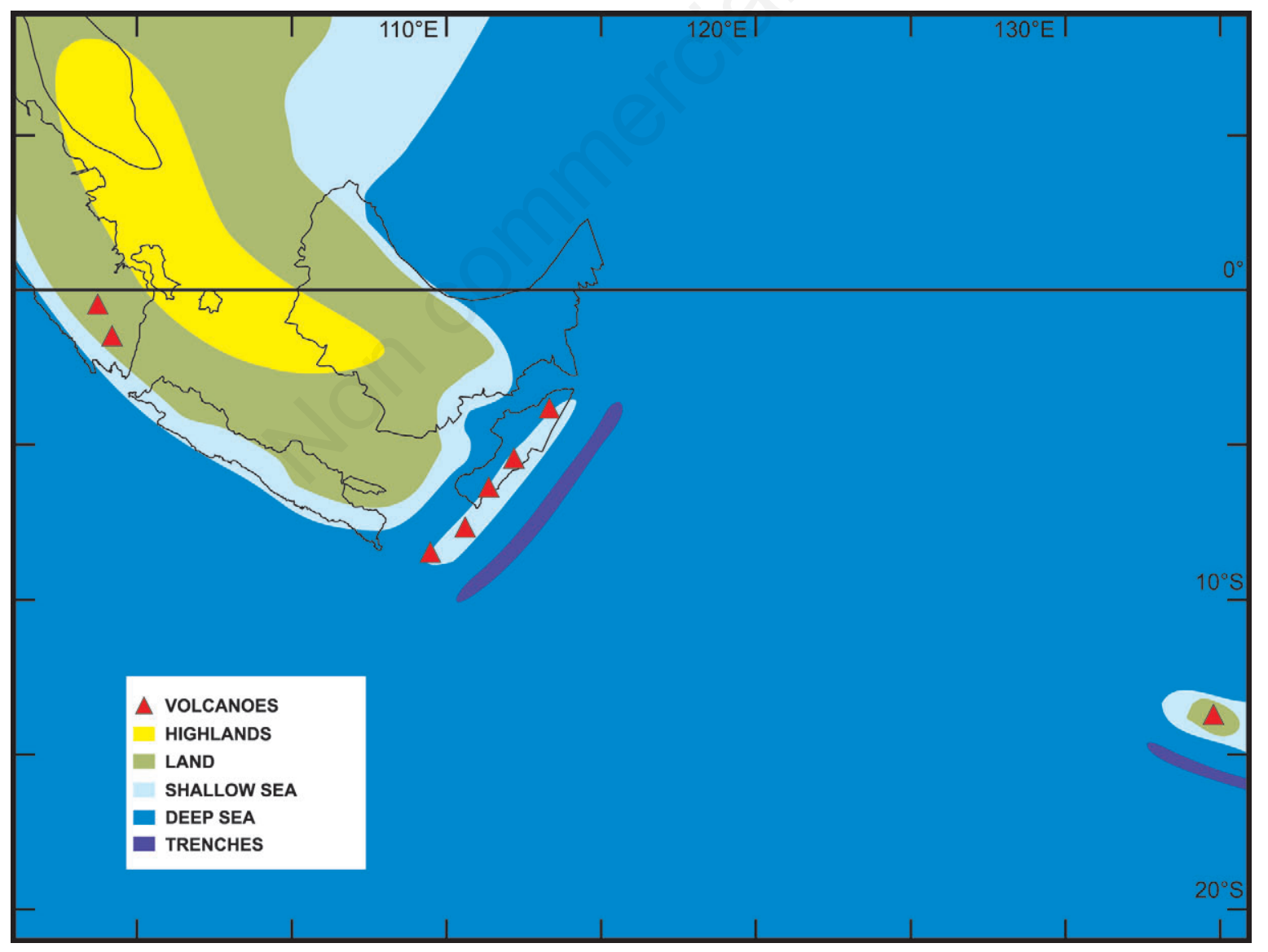

Fig. 3. Palaeogeography at $60 \mathrm{Ma}$ - Paleocene. Much of Sundaland was emergent and there was probably a relatively high interior. There was a volcanic arc at the eastern edge of Sundaland in West Sulawesi and Sumba. 
the Malay Peninsula and the Schwaner Mountains of SW Borneo. Thermochronological studies indicate that subsidence offshore in the Gulf of Thailand and Malay Basin was associated with uplift of the Malay Peninsula. Despite rapid subsidence most basins were not bathymetrically deep features [probably less than $200 \mathrm{~m}$, based on Shoup et al. (2012)] and contain fluviatile and largely marginal marine deposits.

The palaeogeography varied with eustatic sea level fluctuations, but from the Eocene to Early Miocene (Figs. 4-7) most of western Sundaland was terrestrial with deposition in sedimentary basins dominated by fluviatile input, with many often large freshwater lakes. The palaeogeographic maps presented in Figs. 4-9 incorporate detailed outlines of the numerous freshwater and brackish lakes and inland seas which have been mapped by Shoup et al. (2012) and Morley and Morley (2013) from the integration of an extensive seismic and biostratigraphic database. It is likely that the Malay peninsula was an ele- vated region supplying sediment to Sunda shelf basins, and the Schwaner mountains of SW Borneo was another. Parts of the present Java sea such as the Karimunjawa and Bawean arches (Smyth et al., 2003, 2008), which occupy the area between Borneo and Java, may also have been elevated and provided sediment. In the area west of the present Meratus Mountains, known as the Barito basin, there was a wide river system, where peats and fluvial and estuarine sediments were deposited, which appears to have flowed north during the Eocene from the present Java sea (Witts et al., 2012) towards the Makassar straits, with limestones deposited during periods of higher sea level. Clastic sediment was also transported into the North Makassar straits from central or west Borneo. Although the marine area of eastern Borneo increased in size and became deeper, most of the rest of Sundaland was terrestrial with locally small areas of higher elevation.

The part of eastern Indonesia known to biologists as Wallacea dates in part from the Eocene (Fig. 4). Rifting

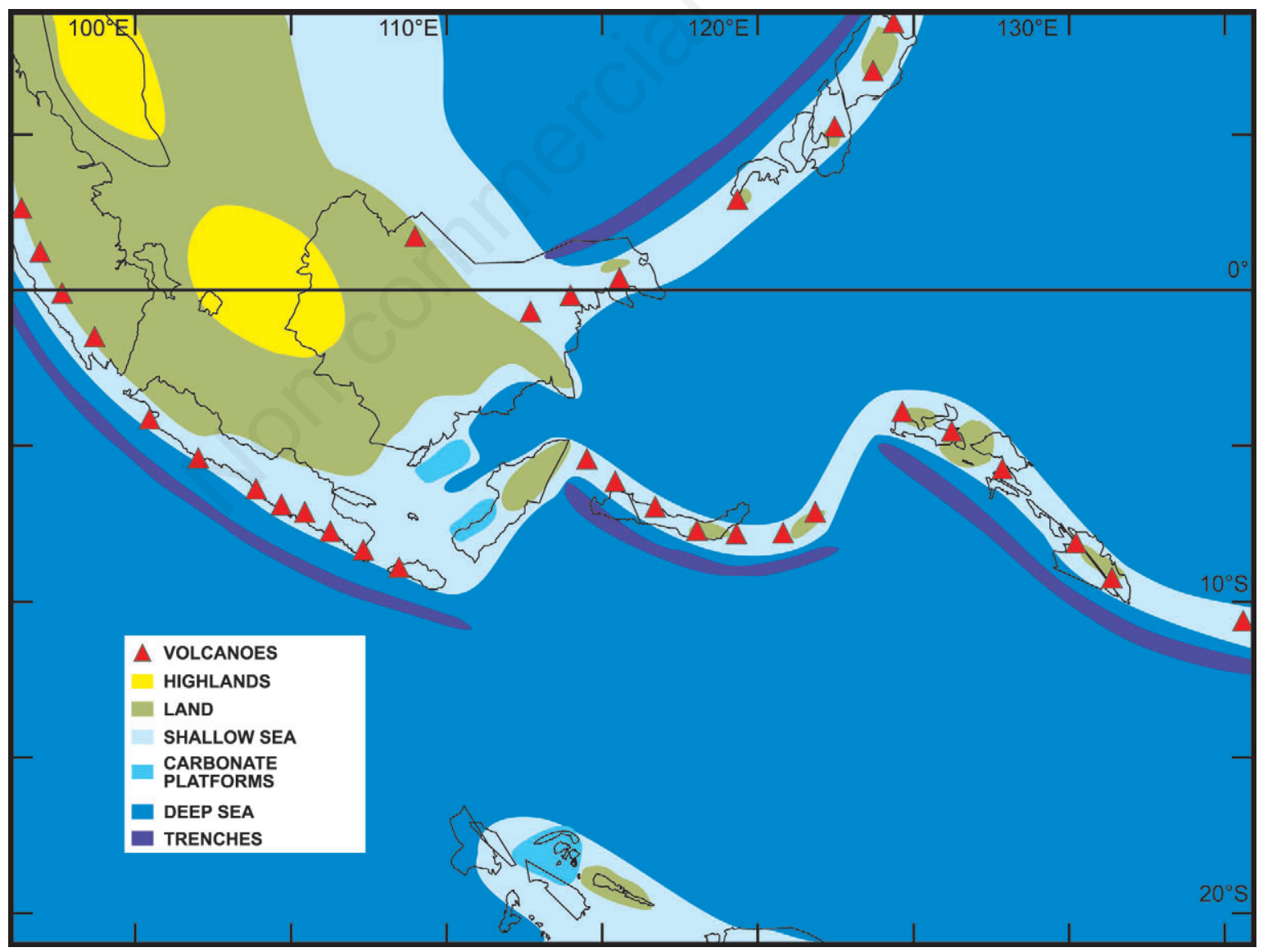

Fig. 4. Palaeogeography at $40 \mathrm{Ma}$ - Late Eocene. Subduction resumed around much of Sundaland in the Middle Eocene and new sedimentary basins were filled mainly by terrestrial sediments. The Makassar straits had become a significant marine gap at the eastern edge of Sundaland, isolating West Sulawesi. 
of the SE Sundaland margin (Hall and Morley, 2004), probably caused by the development of new subduction zones, separated West Sulawesi from Borneo and created the Makassar straits. Initially this was a wide but partly terrestrial gap (alluvial plains crossed by rivers with peaty swamps), and partly shallow marine (shallow marine carbonates and clastic sediments), with elevated ridges parallel to the rift which were locally submerged and capped by shallow water carbonates. By the Oligocene the Makassar straits had become a wide and deep marine barrier within Sundaland (Fig. 5). West Sulawesi was physically isolated from the rest of Sundaland but included land which continued to supply sediment to adjacent offshore areas. SE Sundaland from South Sulawesi to East Java was largely an area of shallow water carbonate deposition.

At the southern margin of Sundaland between the Eocene and Early Miocene (Fig. 6) were volcanic arcs. The volcanoes mainly formed islands rather than continuous and extensive areas of land. In Sumatra volcanic activity became widespread from the Middle Eocene. The Eocene arc was initially constructed on the edge of Sundaland with some volcanic centres in a terrestrial setting and others forming islands on a coastal plain. Later marine transgressions left the volcanic Barisan mountains as a chain of large islands south of the elevated Malay peninsula by the Early Miocene (Fig. 7). In Java there was a se-

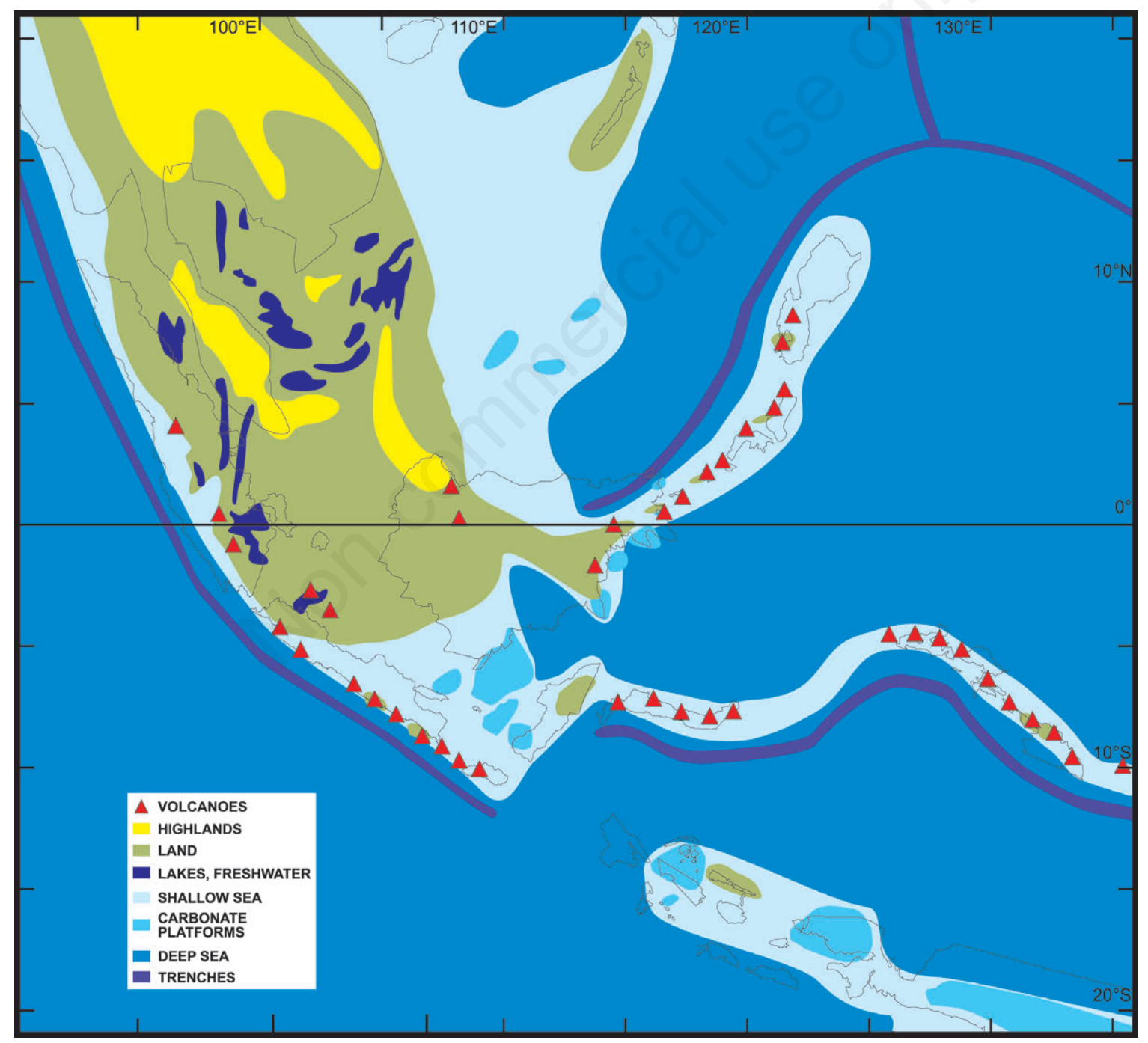

Fig. 5. Palaeogeography at $30 \mathrm{Ma}$ - Mid Oligocene. Although much of Sundaland was emergent it is likely that topography was significantly lower than earlier in the Cenozoic. Rivers carried recycled clastic sediments to internal basins and the continental margins. On the Sunda shelf there were large freshwater lakes, not linked to the ocean. Land remained in West Sulawesi. Details of Sunda shelf freshwater lakes from Morley and Morley (2013). 
ries of small volcanic islands south of the Sundaland coast. From the Eocene to Early Miocene the proto-South China sea was subducted southwards beneath northern Borneo where there was volcanic activity. Deep water areas at the active subduction margin received quartz-rich sediment from the Malay-Thai peninsula and the Schwaner mountains, implying eastward-flowing rivers from granitic source areas. Some material was derived from emergent areas in Sabah where ophiolitic rocks form the basement.

\section{Cenozoic: Neogene}

By the Early Miocene (Fig. 7) the proto-South China sea had been eliminated by subduction, resulting in collision of continental crust of the South China margin with the vol- canic arc of Sabah-Cagayan, leading to emergence, or increase in area, of land in central Borneo, Sabah and Palawan. Australia began to collide with SE Sundaland in Sulawesi about 23 million years ago (Figs. 6 and 7), effectively closing the former deep ocean separating the two continents. These collisions led to mountain building in Borneo, Sulawesi, and the Banda arc. In addition, the arrival of arcs from the Pacific led to the emergence of islands in east Indonesia. They changed the palaeogeography of the region in a significant way by enlarging the area of land in Wallacea, but also leading to an increase in the areas of shallow seas both in Wallacea and further west in Sundaland.

For many years geologists have interpreted the complex geology of Wallacea in terms of collision. Within the context of convergence of Australia and SE Asia many

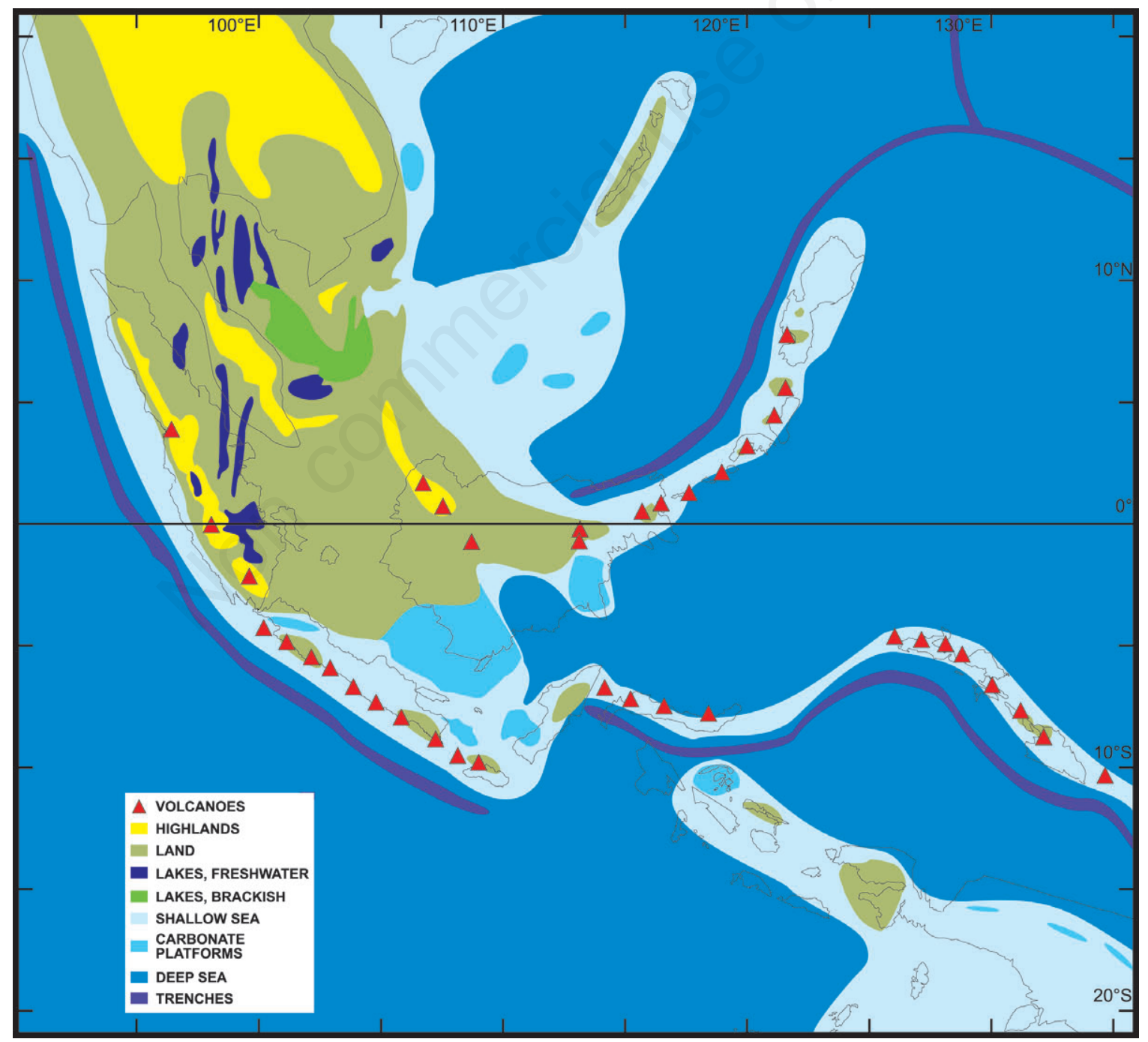

Fig. 6. Palaeogeography at $25 \mathrm{Ma}$ - Late Oligocene. On the Sunda shelf brackish lakes were intermittently connected to the sea. The Sula spur was about to collide with the Sulawesi North Arm volcanic arc. Details of Sunda shelf fresh and brackish water lakes from Morley and Morley (2013). 
features have been interpreted as the result of multiple minor collisions of moving tectonic fragments, often called terranes. The geological terrane concept has become popular with biogeographers as the model appears to account for many complex distribution patterns. However, in Wallacea and New Guinea ideas are changing, and biologists need to exercise caution in applying over-simple geological solutions. The microplate or terrane concept of slicing fragments from New Guinea followed by multiple collisions in Wallacea appears increasingly implausible. Fragmentation has occurred but much of this has been driven by extension, related to subduction, and a much more complex picture of vertical movements, and changing land-sea patterns, is emerging.

\section{Sundaland}

Almost all of southern Sundaland was flat south of the area that today forms the Central Borneo Mountains (Figs. 7 and 8). In SW Borneo there is no Cenozoic record preserved, but Cretaceous granites and metamorphic rocks now exposed in the Schwaner mountains imply a prolonged period of emergence and erosion. Most of

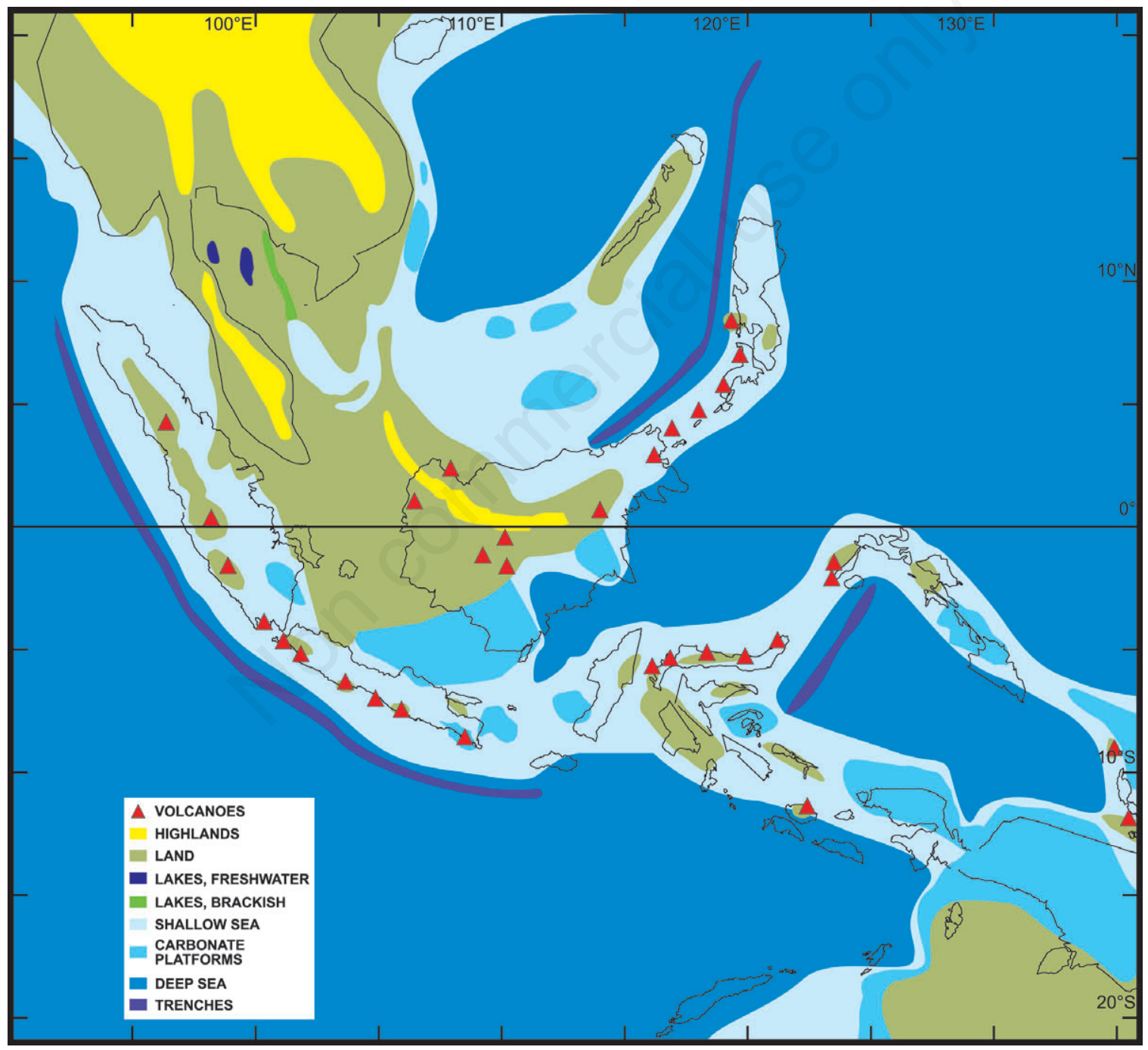

Fig. 7. Palaeogeography at $20 \mathrm{Ma}$ - Early Miocene. There was a marine incursion onto the Sunda shelf. Borneo became an important source of clastic sediments which were carried into deep offshore basins to the north, east and southeast. There were extensive areas of carbonate deposition on wide shallow shelves around Sundaland. After collision in Sulawesi there was uplift and the first links to Australia, although there was no continuous land connection. Much of Wallacea between Sulawesi and the Bird's Head was the site of shallow marine carbonate deposition with some areas of land which are difficult to define. Details of Sunda shelf marine embayments and lakes from Morley and Morley (2013). 
southern Borneo probably remained close to sea level. To the east of the present-day Schwaner mountains, and to the south across the present Java sea, there are Eocene to Miocene terrestrial sediments that represent emergence during intervals of low eustatic sea level and shallow marine limestones that record intervals of higher sea level. Across the East Java sea to South Sulawesi was the longlived Eocene to Miocene Paternoster-Tonasa carbonate platform (Figs. 4-7). All these areas are still largely undeformed with the exception of SE Borneo where the narrow and elongate Meratus mountains ridge (Fig. 9), which represents a reactivated Cretaceous suture, probably rose between the Late Miocene and Pleistocene (Witts et al., 2011; Witts, 2012).
Further north, the Dangerous Grounds are a rifted microcontinental fragment from the South China margin, capped by locally emergent carbonate reefs, shoals and atolls. Parts of this block, and particularly the area that eventually became Palawan, was land as it drifted south between the Eocene and Early Miocene; other parts were submerged but were very shallow marine areas where carbonates were deposited (Figs. 5-7). Subduction of the proto-South China sea ended in the Early Miocene when the Dangerous Grounds block underthrust northern Borneo causing deformation and uplift (Fig. 7). This significantly increased the land area of Palawan and Borneo and formed highlands in the interior of Borneo. Large rivers flowed outwards as Borneo rose and the land area contin-

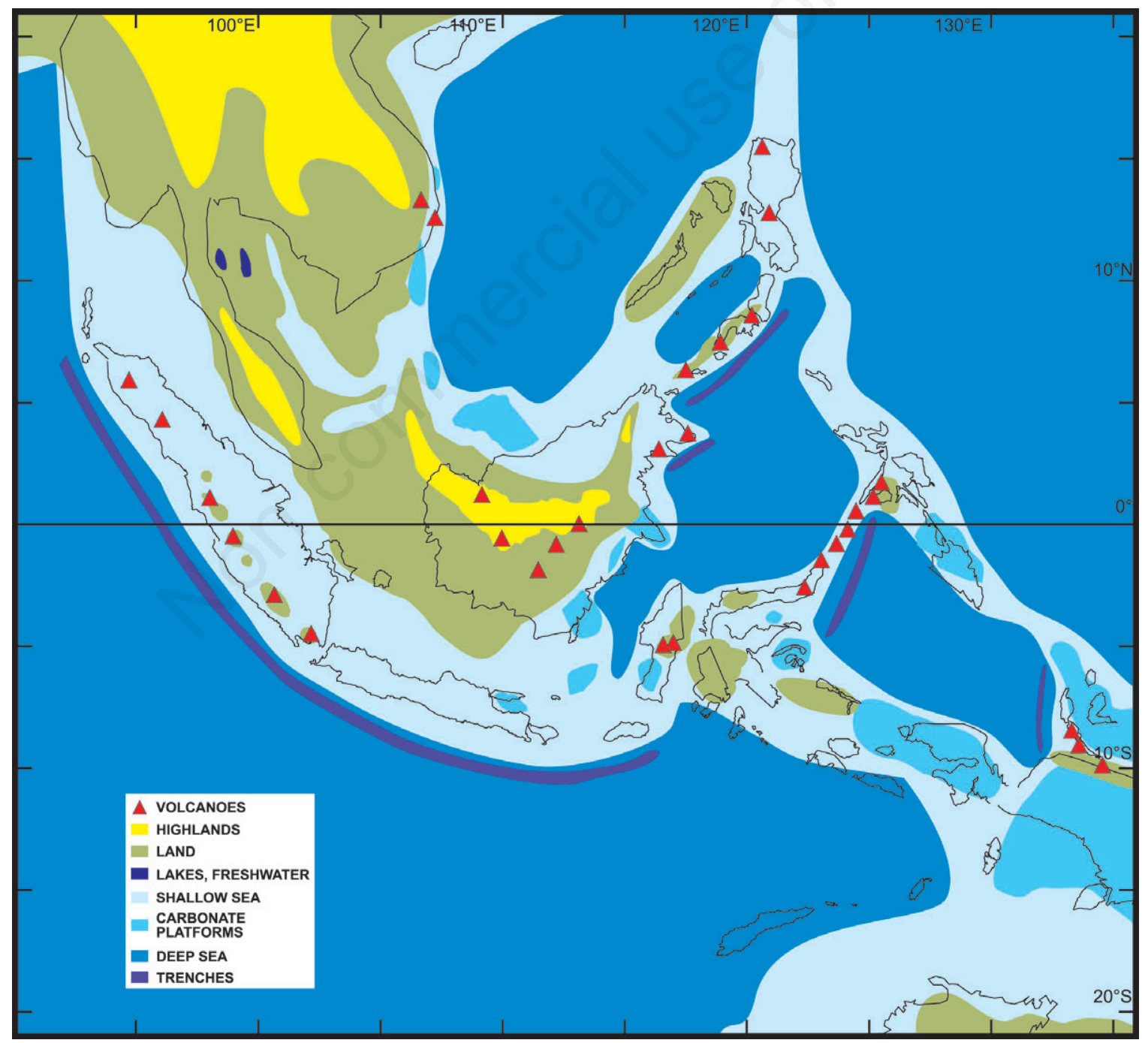

Fig. 8. Palaeogeography at $15 \mathrm{Ma}$ - Mid Miocene. From about $15 \mathrm{Ma}$ the Java subduction zone began to rollback into the Banda embayment. This caused major extension in Sulawesi and began to fragment the Sula spur. Details of Sunda shelf marine embayments from Morley and Morley (2013). 
ued to increase through the Neogene. Pulses of uplift and expansion of land area occurred throughout the Neogene with the most dramatic example being mount Kinabalu in Sabah where recent dating has shown Mio-Pliocene rapid uplift, recorded by a 7-8 Ma granite (Cottam et al., 2010) now exposed at $4 \mathrm{~km}$ above sea level. Kinabalu is one of the few mountains between New Guinea and the Himalayas that was provably capped by ice during the Pleistocene (Hope, 2004). It is one of several mountains in Sabah that have become unusually high in the past few million years and it is likely that the summit was ice-covered and ice-free several times in the last 2 million years.

As Borneo became higher and larger in land area
Palawan seems to have collapsed and become smaller in area. This is probably linked to extension related to subduction of the Celebes sea beneath south Sabah and the Sulu arc. This subduction produced a Middle and Late Miocene volcanic arc in the Dent and Semporna peninsulas of south Sabah and the Sulu islands (Figs. 9 and 10), which although lacking permanent continuous land could have permitted connections between Borneo and the Philippines via intermittently emergent volcanic islands.

In contrast, as Borneo became emergent, the area to the north and west records gradual flooding of the Sunda shelf accompanied by disappearance of freshwater lakes, brackish embayments and a gradual increase in the size

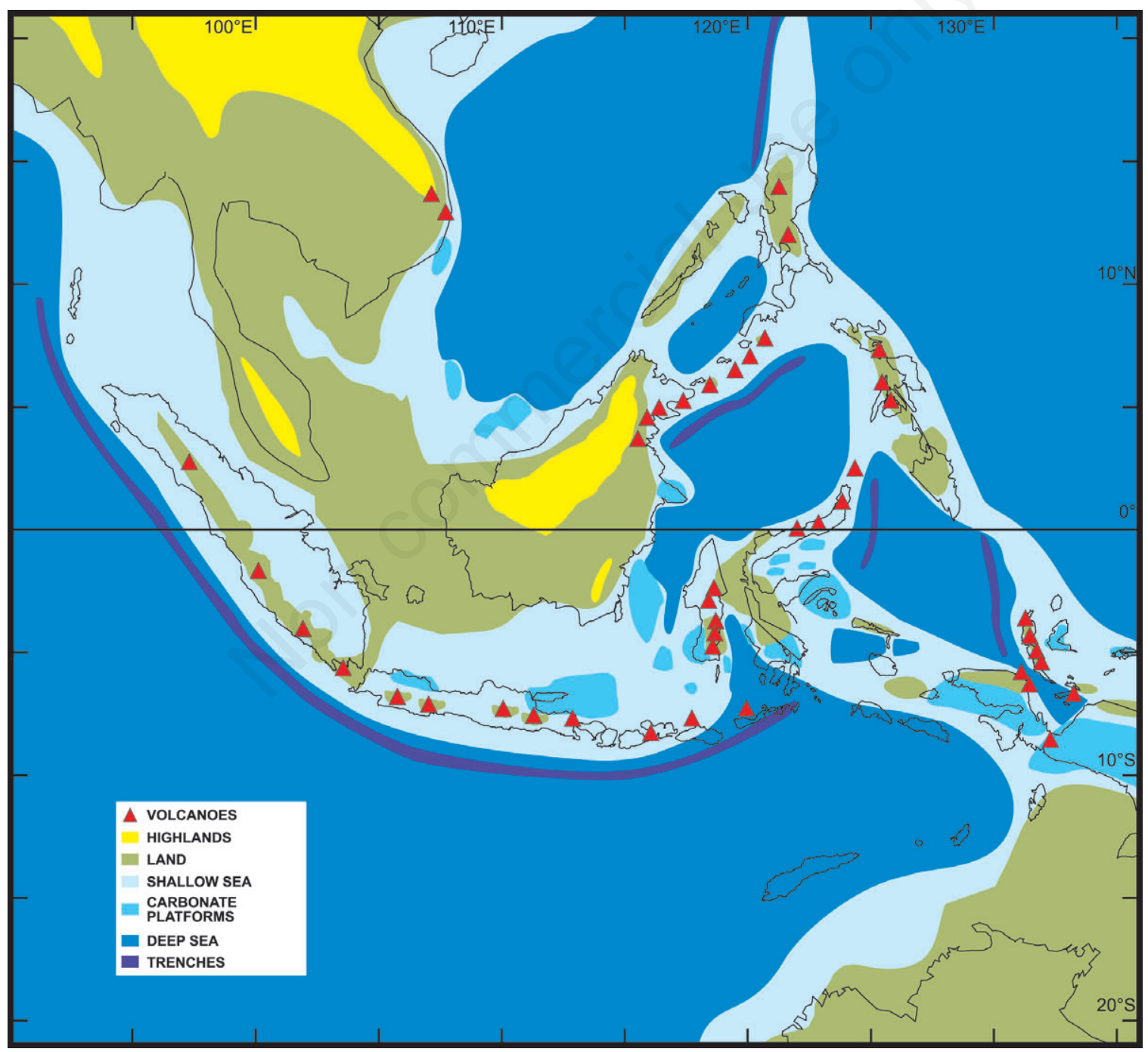

Fig. 9. Palaeogeography at $10 \mathrm{Ma}$ - Late Miocene. Borneo was now a large elevated area. Subduction rollback was well underway and extension in Sulawesi was accompanied by volcanic activity, subsidence of Bone gulf and oceanic crust formation in the North Banda sea, and renewed elevation on land. Wallacea probably had a much more complex palaeogeography than shown. There was no slicing of fragments from the Bird's Head and fragmentation of the Sula spur was the result of extension driven by subduction rollback into the Banda embayment. 
of the marine area extending from the South China sea (Figs. 7-9). Eustatic sea level fluctuations mean that Sunda shelf coastlines and marine areas fluctuated considerably with time as documented offshore using seismic and biostratigraphic data (Shoup et al., 2012; Morley and Morley, 2013).

Sumatra is underlain by continental crust and like the Sunda shelf has been above or close to sea level during the Cenozoic. Since the Middle Miocene the Barisan mountains rose and widened (Figs. 9 and 10), largely due to volcanic activity and strike-slip faulting, and partly in response to region-wide Sundaland deformation following Australian collision in east Indonesia. Subduction-related deformation, reflecting abrupt changes in the age of the subducting Indian ocean crust may also have contributed to elevation of Sumatra and its forearc. From Nias and Siberut the forearc south of the Sumatran coast is extremely shallow and there is almost no deep basin between the forearc high and the coast, as there is to the NW and SE. Several of the large islands, such as Nias and Siberut, were probably connected at times to the Sumatran mainland although this is less likely for the islands further SE.

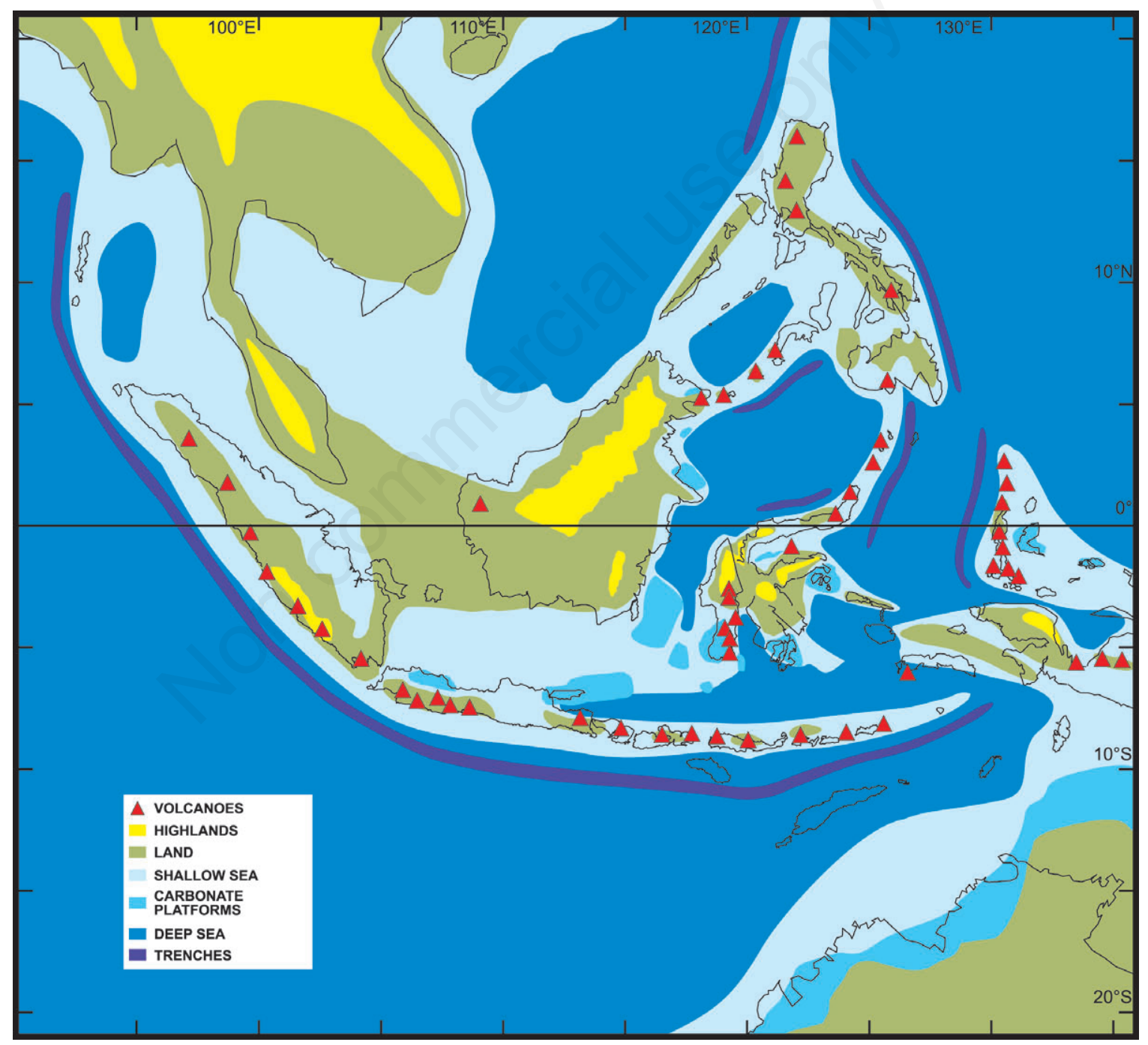

Fig. 10. Palaeogeography at $5 \mathrm{Ma}$ - Early Pliocene. Oceanic spreading in the North Banda sea had ceased but had begun in the South Banda sea and probably the Flores sea. Significant and rapid changes in topography began in Sulawesi, as rollback commenced at the North Sulawesi trench causing widespread extension of North and East Sulawesi. This led to subsidence of Gorontalo bay from a shallow marine carbonate area to present depths of up to $2 \mathrm{~km}$, and further subsidence of Bone bay. Subsidence was accompanied by significant elevation on land. Uplift was about to begin in Timor as the Banda volcanic arc collided with the Australian continental margin. Seram and Timor are the two largest islands in the Banda region to have emerged since 5 Ma. 
In contrast to Sumatra, Java became the large island of today more abruptly and more recently. For most of the Paleogene, northern Java and the Java sea was a shallow shelf that was close to sea level and intermittently emergent. South of the shelf there were prolonged periods of activity in a chain of volcanic islands, except in the Middle Miocene when there was widespread shallow marine carbonate deposition and volcanic activity declined. The volcanic arc moved abruptly northwards at about $7 \mathrm{Ma}$ after arrival at the trench of a buoyant basaltic volcanic province on the Indian plate, causing widespread thrusting throughout Java leading to the emergence of most of West Java. Unusual K-rich volcanoes (for example, Muriah and Ringgit in East Java) erupted near the edge of the Sunda shelf during this interval and normal arc volcanism resumed only in the last 1 to 2 million years, which broadly coincides with the emergence of East Java (Fig. 10) that has made Java the large elongate island of today.

\section{Wallacea}

In Wallacea topography and bathymetry changed very rapidly during the Neogene (Figs. 7-10). This is reflected in the complex passageway for water which moves from the Pacific to the Indian ocean, which probably had local and global climatic consequences, and is a result of a complex tectonic history. A popular geological model for Wallacea suggests that small fragments of continental crust were sliced from the Bird's Head of New Guinea during the Neogene, moved west along a left-lateral strike-slip zone, and collided with Sulawesi. This concept originated with Hamilton (1979) and has been incorporated in many tectonic models and reconstructions. The model has proved popular with biogeographers as this scenario may provide a mechanism for dispersal of organisms from Australia into SE Asia. Our recent work in eastern Indonesia has caused us to doubt it. Instead, we now suggest that there was a collision in the Early Miocene between the Sundaland margin of West and North Sulawesi and an Australian continental promontory, the Sula spur. The promontory extended west from New Guinea on the north side of an oceanic Banda embayment and had formed during Jurassic rifting of the Australian margin. It was later fragmented by extension, not by slicing, as explained below, and the fragments of continental crust scattered around the Banda Arc are almost all the result of this extensional mechanism.

The Sula spur was the first part of the Australian continent to make contact with the Sundaland margin (Figs. 6 and 7) as shown in an animated reconstruction by Spakman and Hall (2010). Collision caused deformation that elevated the eastern parts of Sulawesi and produced a widespread unconformity between Neogene and preNeogene rocks. However, in South Sulawesi shallow marine carbonate deposition continued, as dispersed build-ups, and further north in West Sulawesi there is little indication of mountains and no major deformation. The nature of the boundary between West and East Sulawesi is obscure. The Early and Middle Miocene record is very incomplete, although there are some poorly dated terrestrial and marginal marine sediments, probably because much of East and SE Sulawesi was land (Fig. 7).

After the collision it seems unlikely there was a continuous terrestrial connection from Sulawesi to Australia via the Bird's Head, as in many parts of the former Sula spur and in the Bird's Head there are widespread shallow marine carbonates. However, in the Banggai-Sula islands Cretaceous-Paleocene rocks are overlain in the west by flat-lying Eocene to Recent shallow marine carbonates with a slight angular unconformity, and further east where there are no carbonates the Mesozoic sequence has been eroded to expose a basement window which may have been elevated in the early Cenozoic. It is possible that parts of the islands, and possibly other parts of the Sula spur, could have become emergent during the Eocene and remained as land until the present.

There was an important change in the Middle Miocene at about $15 \mathrm{Ma}$ (Fig. 8) when widespread extension and major subsidence began. This was caused by subduction rollback into the Banda oceanic embayment. Subduction can be caused by convergence between two plates, one of which subducts beneath the other (Fig. 11A), but alternatively can be the result of a plate sinking into the mantle under the influence of gravity (Fig. 11B). As the plate sinks, the subduction zone moves ocean-ward, in a process that has been described as subduction/slab/hinge rollback, or hinge/trench retreat (Hamilton, 2007). The rollback induces extension in the upper plate to fill the space created (Fig. 12). Such extension can cause subsidence and uplift, and both occurred in Sulawesi.

Extension occurred in several phases. The results of these different extensional episodes were formation of the deep oceanic basins of the Banda sea and the inter-arm non-oceanic basins of Gorontalo bay and Bone bay. The North Banda sea formed between 12.5 and 7 Ma (Fig. 9) and the South Banda sea between 6 and 2 Ma (Fig. 10). Both inter-arm bays contain sedimentary sequences that include extensive shallow marine carbonates, showing that before extension they were close to sea level. Bone bay subsided in several phases during Banda subduction rollback. Major extension was also caused by development of the North Sulawesi subduction zone which formed at about $5 \mathrm{Ma}$. Subsidence of Gorontalo bay, to its present depths of up to $2 \mathrm{~km}$, was the result of this subduction rollback.

We can infer that there were quite large and possibly long-lived areas of land in Sulawesi that were, or remained, elevated as rollback occurred. These are indicated by clastic sediments deposited after collision often called 
Celebes Molasse (because of their supposed similarity to the molasse of the Swiss Alps). The Celebes Molasse is thought to have been deposited in the Early to Late Miocene, implying uplift and erosion, but most of the rocks assigned to it are undated, and the best dated are Late Miocene and Pliocene. The inter-arm bays of Gorontalo and Bone contain thick sediment sequences that could have been eroded during the Early to Late Miocene from a mountainous region in East, Central and SE Sulawesi, and in many parts of Central and SE Sulawesi there are metamorphic rocks suggesting significant erosional removal of upper crust cover rocks. Laterites in parts of East Sulawesi also suggest prolonged periods of tropical weathering of a land surface. Present knowledge allows little more than the statement that there was an elevated landmass in Sulawesi during much of the Miocene.

Most of the present relief of Sulawesi (Fig. 13) seems to have been created since the Late Miocene and in the past $5 \mathrm{Ma}$ (Fig. 10) there has been a major increase in land area and a significant change in elevation. There was clearly a major increase in output of clastic sediment at the same time. In Gorontalo bay spectacular very young and rapid subsidence is recorded by numerous carbonate reefs now found at water depths between 1 and $2 \mathrm{~km}$. Pliocene alluvial fan deposits on islands in Gorontalo bay are separated from their equivalents in the East Arm by water depths up to $1.5 \mathrm{~km}$. Seismic lines across Bone bay show similar thick sediments and subsidence history. As these areas subsided from close to sea level to 1 to $2 \mathrm{~km}$ depths the mountains close by rose to their present elevations of 2 to $3 \mathrm{~km}$. Deep valleys incised into steep moun- tains expose deep crustal rocks intruded by young granites throughout West Sulawesi as the upper crust was stripped off. Much of this sediment has been carried west into the Makassar straits. The marine gap that existed since the Eocene has narrowed in the last $5 \mathrm{Ma}$ as Borneo has emerged and Sulawesi has risen, but the central part of the Makassar straits may have become deeper in response to gravity-driven movements of material from Sulawesi.

Almost all the non-volcanic islands of the Outer Banda arc (Fig. 13) have emerged in the last $3 \mathrm{Ma}$. As the subduction zone rolled back into the Banda embayment the inner volcanic arc was active and moved with it. At about $4 \mathrm{Ma}$ the volcanic arc collided with the southern passive Australian continental margin of the Banda embayment in East Timor. In Timor and Sumba the arc-continent collision was marked by rapid uplift which moved sedimentary rocks deposited at depths of several kilometres below sea level to their present positions of more than one kilometre above sea level. Islands such as Savu, Roti and Tanimbar have emerged even more recently. Volcanic activity ceased in Wetar and Alor in the mid Pliocene by about 2 million years ago although it continued in the very young islands of the eastern arc from Damar to Banda. Islands have formed at different times since the Late Miocene, and many parts of Wallacea have emerged at very high rates, for example in Timor Audley-Charles (1986) estimated average rates of uplift of $1.5 \mathrm{~km} / \mathrm{Myr}$. Other large islands such as Seram, Buru, Sumba and parts of Sulawesi probably rose at similar rates, but as they did so, basins like the South Banda sea and Weber deep have subsided.
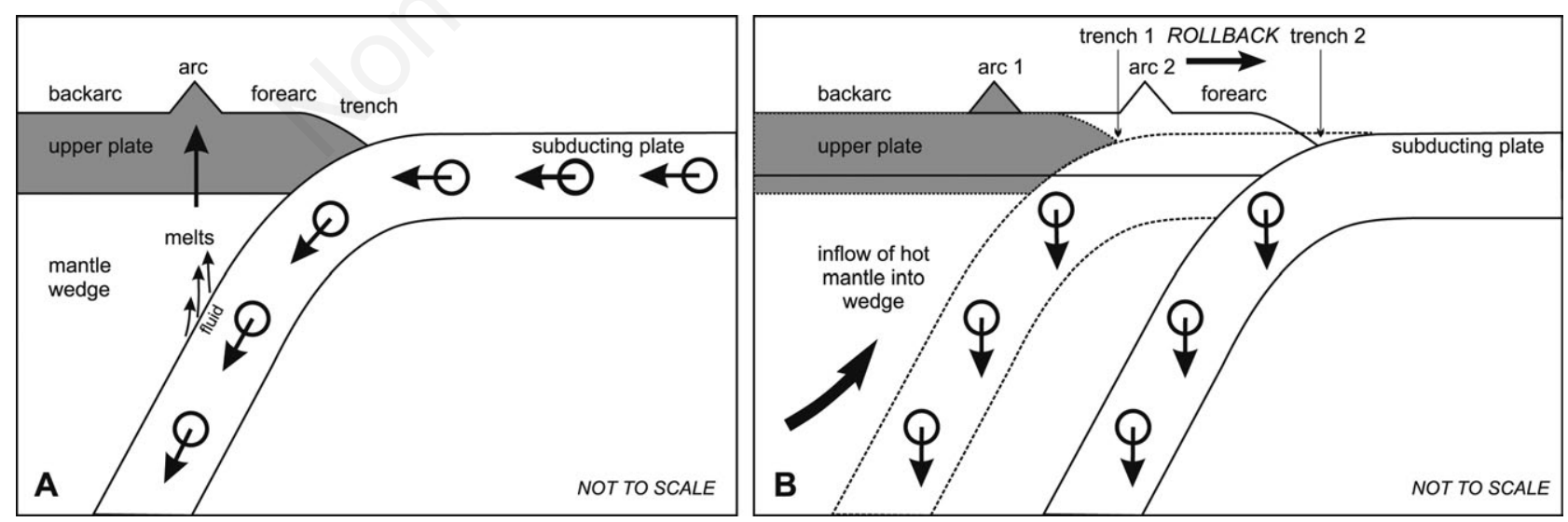

Fig. 11. Subduction can be viewed in two ways. A) A conventional view of subduction in which one plate is moving towards a stationary upper plate and is subducted beneath it. Magmas are produced at the volcanic arc as water is released from the subducted plate and its sedimentary cover, causing melting of the mantle wedge above the subducted plate. In this model the trench and arc remain in a fixed position. B) An alternative view of subduction in which the subducted plate falls into the mantle under the influence of gravity. Subduction is maintained by rollback of the subduction hinge which results in the movement of the trench and arc in an oceanward direction. Subduction can be maintained without any convergence between the plates. The upper plate must extend and thin, and new mantle must rise into the wedge, to allow rollback to continue. 
At the eastern edge of Wallacea are the Halmahera and Sangihe volcanic arcs which are currently colliding. Both these arcs formed during the Neogene. The Sangihe arc can be traced from Sulawesi northwards into the Philippines. In biogeographic terms it is within Wallacea but in geological terms is arguably part of Neogene Sundaland. It was constructed on Eocene oceanic crust of the Celebes sea at the edge of Sundaland, but in the Neogene linked the North Arm of Sulawesi which had previously collided with the Sula spur to the Philippines
(Figs. 9 and 10). The modern Halmahera arc is a relatively recent arrival in Wallacea. It is constructed on older intra-oceanic arcs formed in the Pacific which were part of the Philippine sea plate. Before $25 \mathrm{Ma}$, the Philippines-Halmahera arc was an intra-oceanic Pacific arc, formed above a north-dipping subduction zone as Australia moved north. These arcs collided with northern Australia at about $25 \mathrm{Ma}$ and then moved west along the New Guinea margin north of the left-lateral Sorong fault zone (Figs. 9 and 10). Like the islands of the Banda re-

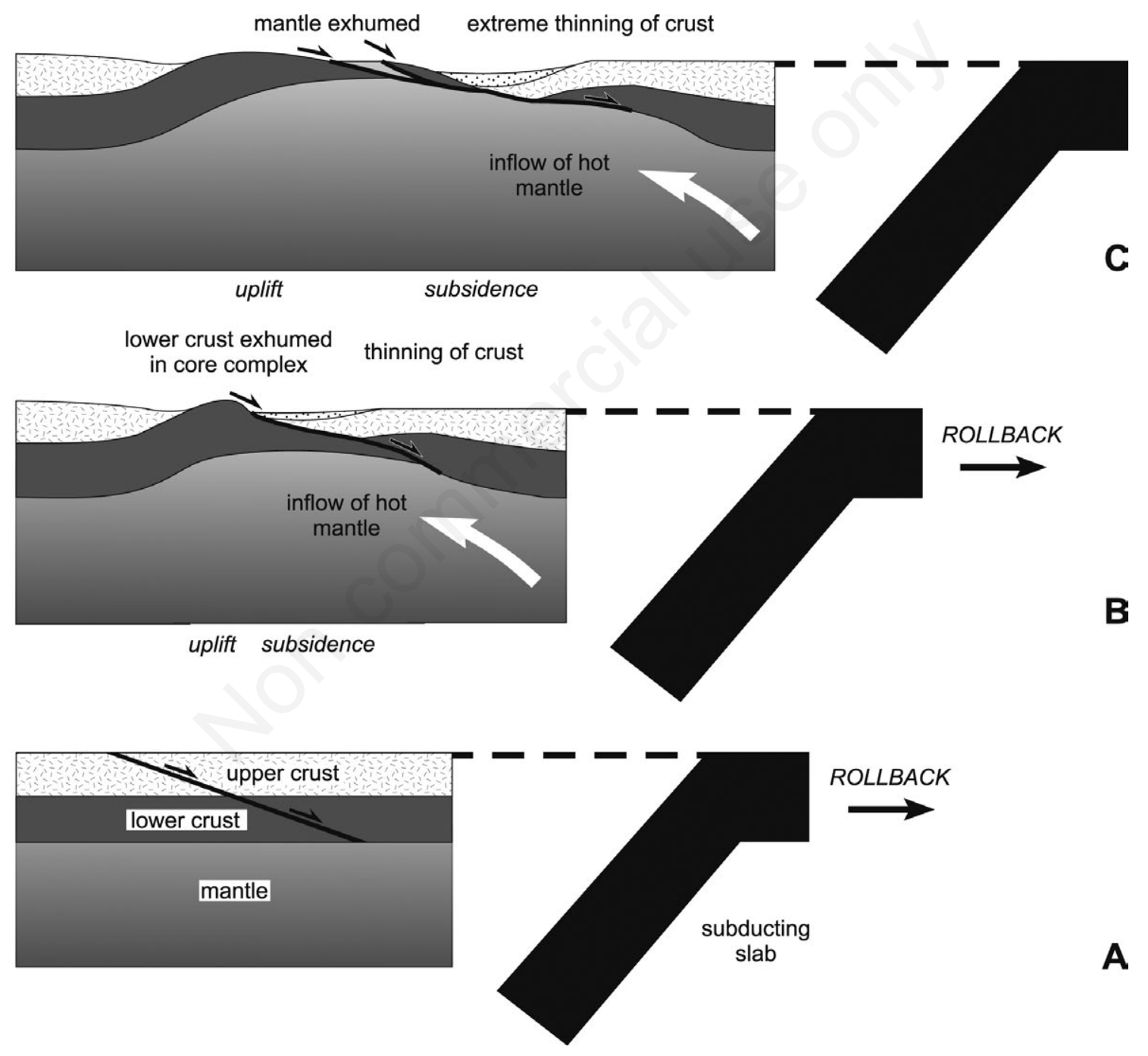

Fig. 12. Cartoons to illustrate how extension of the upper plate may occur during subduction rollback. A) The initial situation in which there is subduction beneath continental crust, simplified into upper and lower parts, and mantle. Extension is accomplished by the development of major faults that cut through the entire crust. B) As rollback proceeds a major detachment fault cuts through the crust causing part of the lower crust to be exhumed. Thinning and inflow of mantle below the stretched crust cause uplift of the thinned lower crust and subsidence of the thinned upper crust. Melting may occur in the thinned region due to increased heatflow as hot mantle rises. C) If extension continues the crust may be completely broken, allowing mantle to reach the surface or leading to formation of new ocean crust between stretched remnants of continental crust. Both uplift and subsidence accompany extension. 
gion they are probably larger areas of land now than at any time in the past.

Major changes in sea level during the Pleistocene caused intermittent emergence of the shelf areas of Sunda and Australia (Fig. 13); modern bathymetric maps and the history of global sea level can be used to infer the distribution of land and sea (Voris, 2000). At times the islands around the Sunda shelf were connected and the entire shelf was emergent. However, even at times of lowest sea level during Pleistocene glacial intervals the Makassar straits were never narrower than about $75 \mathrm{~km}$ and must have been a formidable barrier since most of the water carried from the Pacific to the Indian ocean by the Indonesian throughflow passes by this route (Godfrey, 1996; Gordon, 2005; Tillinger, 2011). Thus, as sea level fell current velocities probably increased.

Even for the Sunda shelf the method of using modern bathymetry to infer the positions of coastlines is probably valid only for the Pleistocene, and for longer periods it is doubtful whether eustatic changes in sea level can be reliably obtained by stratigraphic analysis of offshore seismic data (Moucha et al., 2008). For Wallacea the problem is even greater. Glacially-drive sea level change would have had little effect on Wallacea where shelves surround-

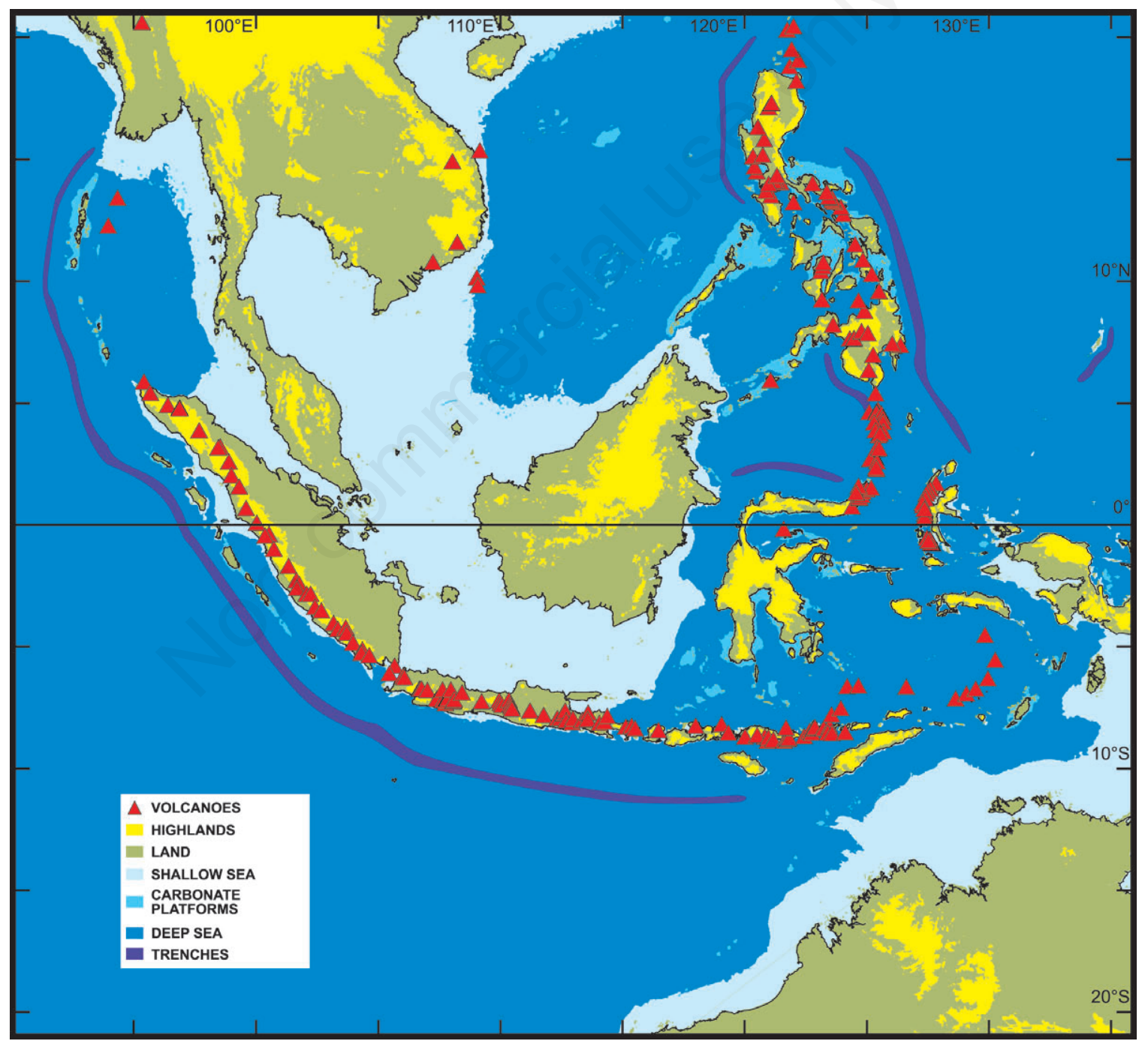

Fig. 13. Palaeogeography at the present day for comparison with the other palaeogeographical maps. Topography is from merged global bathymetry and Shuttle radar topography mission (SRTM) data (Sandwell and Smith, 2009). Volcanoes are from Siebert and Simkin (2002). The edge of the shallow shelves is drawn at the $120 \mathrm{~m}$ bathymetric contour, which is almost identical in position to the $200 \mathrm{~m}$ contour used in Fig. 1. The shallow shelves are the area that would have been emergent during the Last Glacial Maximum approximately 20,000 years ago. Highlands are areas above $500 \mathrm{~m}$. The map underestimates the areas of carbonates on the shelves. 
ing islands are narrow, and shelf edges very steep. Tectonic change has been significant on geologically short time scales. In many parts of Wallacea, vertical movements (both up and down) up to $1.5 \mathrm{~km} / \mathrm{Ma}$ have been recorded and similar rates can be estimated in the Banda region and Sulawesi which indicate the possibility of significant palaeogeographical change within time periods of less than a million years. The geography of the Wallacea has changed very significantly in the last $5 \mathrm{Ma}$, and the overall trend has been a significant increase in land area, and an increase in elevation (Fig. 13).

\section{CONCLUSIONS}

We are still far from a complete understanding of the geology of Sundaland and Wallacea, still less the links to palaeogeography, ocean-atmosphere circulation and climate which have influenced biological change, biogeographical patterns and biodiversity. The maps in this paper are still very broad-brush attempts at showing palaeogeography. The palaeogeography of the Sunda shelf is now becoming clearer from offshore seismic data and dating of sedimentary sequences, and because tectonic effects are less important there than in eastern Indonesia. Wallacea remains a challenge because of the speed of tectonic change and our incomplete knowledge of its consequences. Mountains have disappeared and risen, deep waterways have closed and opened, and ephemeral islands have provided connections. Rapid vertical movements may mean there was more land than previously expected and perhaps more short-lived stepping stones. Geologists have most difficulty with the terrestrial record which is typically incomplete and poorly dated. Biologists can help us with reliable information on evolution and distributions of plants and animals.

\section{ACKNOWLEDGMENTS}

Work by the SE Asia Research Group has been funded over many years by a consortium of oil companies. In addition, the SE Asia Research Group has received support at times from the University of London Central Research Fund, the Natural Environment Research Council, and the Royal Society. I thank Pusat Survei Geologi Bandung, Lemigas, Indonesian Institute of Sciences, and Institut Teknologi Bandung, for assistance and many colleagues, friends and students in the UK, Europe and SE Asia for help and discussion. I am especially grateful to Bob Morley and Duncan Witts for assistance with the palaeogeographical maps. I thank Tony Barber and Bob Morley for review comments on the manuscript.

\section{REFERENCES}

Abdullah NT, 2009. Mesozoic stratigraphy, p. 87-131. In: C.S. Hutchison and D.N.K. Tan (eds.), Geology of peninsular
Malaysia. University of Malaya and Geol. Soc. Malaysia ed. Ali JR, Aitchison JC, 2008. Gondwana to Asia: plate tectonics, paleogeography and the biological connectivity of the Indian sub-continent from the Middle Jurassic through latest Eocene (166-35 Ma). Earth-Sci. Rev. 88:145-166.

Audley-Charles MG, 1986. Rates of Neogene and Quaternary tectonic movements in the Southern Banda Arc based on micropalaeontology. J. Geol. Soc. London 143:161-175.

Clements B, Burgess P, Hall R, 2011. Subsidence and uplift by slab-related mantle dynamics: A driving mechanism for the Late Cretaceous and Cenozoic Evolution of Continental SE Asia? Geol. Soc. London Spec. Publ. 355:37-51.

Cottam MA, Hall R, Sperber C, Armstrong R, 2010. Pulsed emplacement of the Mount Kinabalu Granite, North Borneo. J. Geol. Soc. London 167:49-60.

Davies L, Hall R, Armstrong R, 2012. Cretaceous crust beneath $\mathrm{SW}$ Borneo: U-Pb dating of zircons from metamorphic and granitic rocks. Available from: http://fallmeeting.agu.org/ 2012/eposters/eposter/t43e-2714/

Fontaine H, 1990. The Terbat formation of Sarawak (Malaysia): a very peculiar limestone, p. 173-181. In: H. Fontaine (ed.), Ten years of CCOP research on the Pre-Tertiary of East Asia. CCOP Technical Publication Bangkok.

Godfrey JS, 1996. The effect of the Indonesian Throughflow on ocean circulation and heat exchange with the atmosphere: a review. J. Geophys. Res. 101:12217-12238.

Gordon AL, 2005. Oceanography of the Indonesian Seas and their Throughflow. Oceanography 18:14-27.

Hall R, 1996. Reconstructing Cenozoic SE Asia. In: R. Hall and D.J. Blundell (eds.), Tectonic evolution of SE Asia. Geol. Soc. Spec. Publ. 106:153-184.

Hall R, 1998. The plate tectonics of Cenozoic SE Asia and the distribution of land and sea, p. 99-131. In: R. Hall and J.D. Holloway (eds.), Biogeography and geological evolution of SE Asia. Backhuys Publ.

Hall R, 2001. Cenozoic reconstructions of SE Asia and the SW Pacific: changing patterns of land and sea, p. 35-56. In: I. Metcalfe, J.M.B. Smith, M. Morwood and I.D. Davidson (eds.), Faunal and floral migrations and evolution in SE Asia-Australasia. A.A. Balkema (Swets and Zeitlinger Publ.).

Hall R, 2002. Cenozoic geological and plate tectonic evolution of SE Asia and the SW Pacific: computer-based reconstructions, model and animations. J. Asian Earth Sci. 20:353-434.

Hall R, 2009. SE Asia's changing palaeogeography. Blumea 54:148-161.

Hall R, 2011. Australia-SE Asia collision: plate tectonics and crustal flow. Geol. Soc. Spec. Publ. 355:75-109.

Hall R, 2012a. Late Jurassic-Cenozoic reconstructions of the Indonesian region and the Indian Ocean. Tectonophysics 570571:1-41.

Hall R, 2012b. Sundaland and Wallacea: geology, plate tectonics and palaeogeography, p. 32-78. In: D.J. Gower, K.G. Johnson, J.E. Richardson, B.R. Rosen, L. Rüber and S.T. Williams (eds.), Biotic evolution and environmental change in Southeast Asia. The Systematics Association, Cambridge University Press.

Hall R, Morley CK, 2004. Sundaland Basins, p. 55-85. In: P. Clift, P. Wang, W. Kuhnt and D.E. Hayes (eds.), ContinentOcean interactions within the East Asian marginal Seas. Union ed. 
Hall R, Sevastjanova I, 2012. Australian crust in Indonesia. Aust. J. Earth Sci. 59:827-844.

Hamilton WB, 1979. Tectonics of the Indonesian region 1078. US Government Printing Office, Washington DC, USA.

Hamilton WB, 2007. Driving mechanism and 3-D circulation of plate tectonics. Geol. S. Am. S. 433:1-25.

Hope GS, 2004. Glaciation of Malaysia and Indonesia, excluding New Guinea. Elsevier, London: 388 pp.

Hutchison CS, 1996. The 'Rajang Accretionary Prism' and 'Lupar Line' problem of Borneo. Geol. Soc. Spec. Publ. 106:247-261.

Hutchison CS, 2005. Geology of North-West Borneo. Elsevier, Amsterdam: 444 pp.

Metcalfe I, 2011. Palaeozoic-Mesozoic History of SE Asia. Geol. Soc. Spec. Publ. 355:7-35.

Morley RJ, Morley HP, 2013. Mid Cenozoic freshwater wetlands of the Sunda region. J. Limnol. 72(Suppl.2):e2.

Moucha R, Forte AM, Mitrovica JX, Rowley DB, Quéré S, Simmons NA, Grand SP, 2008. Dynamic topography and longterm sea-level variations: there is no such thing as a stable continental platform. Earth Planet. Sc. Lett. 271:101-108.

Muller J, 1968. Palynology of the Pedawan and Plateau Sandstone Formations (Cretaceous - Eocene) in Sarawak, Malaysia. Micropaleontology 14:1-37.

Racey A, Goodall JGS, 2009. Palynology and stratigraphy of the Mesozoic Khorat group of NE Thailand. Geol. Soc. Spec. Publ. 315:67-81.

Sandwell DT, Smith WHF, 2009. Global marine gravity from retracked Geosat and ERS-1 altimetry: ridge segmentation versus spreading rate. J. Geophys. Res. 114:B01411.

Shoup RC, Morley RJ, Swiecicki T, Clark S, 2012. Tectonostratigraphic framework and Tertiary paleogeography of Southeast Asia: Gulf of Thailand to South Vietnam Shelf. Available from: http://www.searchanddiscovery.com/documents/2012/30246shoup/ndx_shoup.pdf

Siebert L, Simkin T 2002. Volcanoes of the world: an illustrated catalog of Holocene volcanoes and their eruptions. Available from: http://www.volcano.si.edu

Smyth H, Hall R, Hamilton J, Kinny P, 2003. Volcanic origin of quartz-rich sediments in East Java. Proc. $29^{\text {th }}$ Ann. Conv. Indonesian Petroleum Ass., Jakarta, 541-559 p.

Smyth HR, Hamilton PJ, Hall R, Kinny PD, 2007. The deep crust beneath island arcs: inherited zircons reveal a Gondwana continental fragment beneath East Java, Indonesia. Earth Planet. Sc. Lett. 258:269-282.

Smyth HR, Hall R, Nichols GJ, 2008. Significant volcanic contribution to some quartz-rich sandstones, East Java, Indonesia. J. Sedimt. Res. 78:335-356.

Spakman W, Hall R, 2010. Surface deformation and slab-mantle interaction during Banda Arc subduction rollback. Nat. Geosci. 3:562-566.

Tillinger D, 2011. Physical oceanography of the present day Indonesian Throughflow. Geol. Soc. Spec. Publ. 355:267-281.

Tongkul F, 1991. Tectonic evolution of Sabah, Malaysia. J. Southe. Asian Earth 6:395-406.

Voris HK, 2000. Maps of Pleistocene sea levels in Southeast Asia: shorelines, river systems and time durations. J. Biogeogr. 27:1153-1167.

Vozenin-Serra C, 1977. [Contribution à l'étude de la Paléoflore du Sud-est Asiatique (Cambodge, Laos, Vietnam)]. [PhD Thesis in French]. University of Paris ed., France.

Witts D, 2012. Stratigraphy and sediment provenance: the Barito Basin, Southeast Kalimantan, Indonesia. PhD Thesis. Royal Holloway University of London ed., London.

Witts D, Hall R, Morley R, BouDagher-Fadel MK, 2011. Stratigraphy and sediment provenance, Barito Basin, Southeast Kalimantan. Proc. $35^{\text {th }}$ Ann. Conv. Indonesian Petroleum Ass. IPA11-G-054, pp. 1-18.

Witts D, Hall R, Nichols G, Morley R, 2012. A new depositional and provenance model for the Tanjung formation, Barito Basin, SE Kalimantan, Indonesia. J. Asian Earth Sci. 56:77-104. 